\title{
Bilateral choroidal neovascularization response to unilateral intravitreal Ranibizumab injection in a patient with angioid streaks
}

\author{
Resposta de neovascularização bilateral de coróide \\ à injeção unilateral de Ranibizumabe intravítreo \\ de paciente com estrias angióides
}

Otacílio de Oliveira Maia Júnior ${ }^{1}$, Beatriz Sayuri Takahashi ${ }^{2}$, Ricardo Luz Leitão Guerra ${ }^{3}$, Walter Yukihiko Takahashi ${ }^{4}$, Roberto Lorens Marback ${ }^{5}$

\begin{abstract}
Report of a 48 year-old male with bilateral decrease in vision due to choroidal neovascularization secondary to angioid streaks. Best corrected visual acuity was 20/80 in the right eye and counting fingers at 2 meters on the left eye. Patient underwent intravitreal injection of Ranibizumab (Lucentis) in the eye with worse visual acuity. Fifteen days after treatment patient reported better visual acuity on the fellow eye, which was measured to be 20/25. Treatment result was evaluated with visual acuity and optical coherence tomography. The effect of ranibizumab was observed in the treated eye, but the fellow eye had complete resolution of the choroidal neovascularization complex. This result may be a response to systemic absorption of the medication.
\end{abstract}

Keywords: Angioid streaks; Retinal diseases; Retina/pathology; Angiogenesis inhibitors.

\section{RESUMO}

Os autores descrevem paciente do sexo masculino, 48 anos, com diminuição visual bilateral há 15 dias por membrana neovascular sub-retiniana secundária a estrias angióides. A acuidade visual com melhor correção no olho direito era 20/80 e no olho esquerdo de conta dedos a 2 metros. Submetido à injeção intravítrea de Ranibizumabe (Lucentis) no olho com pior acuidade visual. Após 15 dias do tratamento, referiu melhora acentuada da visão no olho contralateral com visão de 20/25. O resultado foi avaliado por meio da acuidade visual e da tomografia de coerência óptica. O efeito do ranibizumabe foi observado no olho tratado, mas no olho contralateral houve completa resolução do complexo da membrana neovascular sub-retiniana. Levanta-se a hipótese de que esse resultado possa ser atribuído à absorção sistêmica da medicação.

Descritores: Estrias angióides; Doenças retinianas; Retina/patologia; Inibidores da angiogênese

\footnotetext{
${ }^{1}$ Vitreoretinal specialist at the Department of Ophthalmology, Hospital São Rafael, Monte Tabor Foundation - Salvador (BA), Brazil;

${ }^{2}$ Vitreoretinal specialist at the Department of Ophthalmology, Universidade de São Paulo (USP) - São Paulo (SP), Brazil:

${ }^{3}$ Fellow in retina at the Department of Ophthalmology, Hospital São Rafael, Monte Tabor Foundation - Salvador (BA), Brazil;

${ }^{4}$ Head of the vitreoretinal service, Department of Ophthalmology, Universidade de São Paulo (USP) - São Paulo (SP), Brazil;

${ }^{5}$ Head of the Department of Ophthalmology, Hospital São Rafael, Monte Tabor Foundation - Salvador (BA), Brazil.
}

Study from the retina and vitreous service, Hospital São Rafael - Monte Tabor Foundation - Salvador (BA), Brazil

The authors declare no conflicts of interest

Recebido para publicação em 28/3/2012 - Aceito para publicação em 3/9/2012

Rev Bras Oftalmol. 2013; 72 (4): 274-7 


\section{INTRODUCTION}

C horoidal neovascularization (CNV) is the major cause of severe visual loss in patients with angioid streaks. Studies also have found evidence of CNV (active or inactive) in the fellow eyes of $71 \%$ of cases undergoing treatment ${ }^{(1)}$.

In recent years, several studies have reported promising results with off-label use of the intravitreal anti-vascular endothelial growth factor-A (VEGF-A) drug bevacizumab (Avastin) for the treatment of CNV related to angioid streaks (2). It has been hypothesized that ranibizumab (Lucentis, Genentech Inc., South San Francisco, CA), which is a humanized antibody fragment designed to bind and inhibit all VEGF-A isoforms, and approved anti-VEGF-A treatment for CNV related to age-related macular degeneration, would offer an outcome at least similar to that of bevacizumab. Lucentis has shown great efficacy in the management of all kinds of lesions in different clinical trials. Nevertheless, only few studies demonstrate the antiVEGF effect in fellow eyes ${ }^{(3-5)}$.

The purpose of this report is to document the resolution of $\mathrm{CNV}$ after intravitreal ranibizumab in the fellow eye in a patient with bilateral choroidal neovascularization secondary to angioid streaks with no previous treatment.

\section{CASE RePORT}

Forty eight year-old male was refered to Hospital Sao Rafael with bilateral decrease of visual acuity and metamorphopsia for the past 15 days. He denied previous eye treatments or diseases. He has medication controlled hypertension.

On examination, best corrected visual acuity was 20/80 in the right eye and counting fingers at 2 meters in the left eye. Biomicroscopy examination and intraocular pressure were within the normal limits.

On fundoscopy, both eyes had multiple brown grayish bands, radially from the optic nerve, characteristic of angiod streaks and an elevated hemorragic leasion in the macula. Fluorescein angiography (Fundus Camera System TRC-50X/ IMAGEnet; Topcon, Tokyo, Japan) showed an active juxtafoveal classic CNV in right eye, and a subfoveal predominantly classic CNV in left eye. RTVue spectraldomain optical coherence tomography (OCT) (Optovue Inc, Fremont, California, USA) showed the neovascular complex in both maculas (figure 1). The patient had no systemic manifestation of any disease related to angioid streaks and denied scratching the eye.

Upon discussion of the therapeutic options available, it was chosen to treat the worst eye (left eye) with an intravitreal injection of $0.5 \mathrm{mg}$ de ranibizumab (Lucentis). This procedure was performed after informed consent, including the fact that results and safety of such treatment in angiod streaks is not well documented. Within 15 days, patient reported mild recovery of vision in the left eye, with vision of 20/400 and recovery of vision of the fellow eye, with 20/25 vision. OCT showed full regression of the neovascular complex on the right eye and partial regression on the treated eye (figure 2).

\section{Discussion}

Although various treatments modalities for $\mathrm{CNV}$ associated with angiod streaks have been assessed, including argon laser photocoagulation, photodynamic therapy, selective occlusion and surgical removal, poor or contradictory results are often reported. In recent years, several studies have reported promising results with use of the intravitreal anti-VEGF-A. To the best of our knowledge, there is only another case of treatment naive CNV secondary to angiod streaks treated with ranibizumab. In the same report, three monthly injections were given and visual acuity remained 20/20 with resolution of subjective visual distortion; fluorescein angiography revealed complete regression of the neovascular complex. All findings were stable until the last follow-up at 27 months. ${ }^{(6)}$ This fact suggests that VEGF-A may play an important role in the pathogenesis of CNV caused by angiod streaks.

Some authors have already demonstrated the effect of antiVEGF on the fellow eye in different diseases. Al-Dhibi and Khan reported bilateral reduction of uveitic cystoid macular edema following unilateral intravitreal bevacizumab injection in an 8year-old girl ${ }^{(3)}$. Neri et al. reported a case of fellow eye vitritis
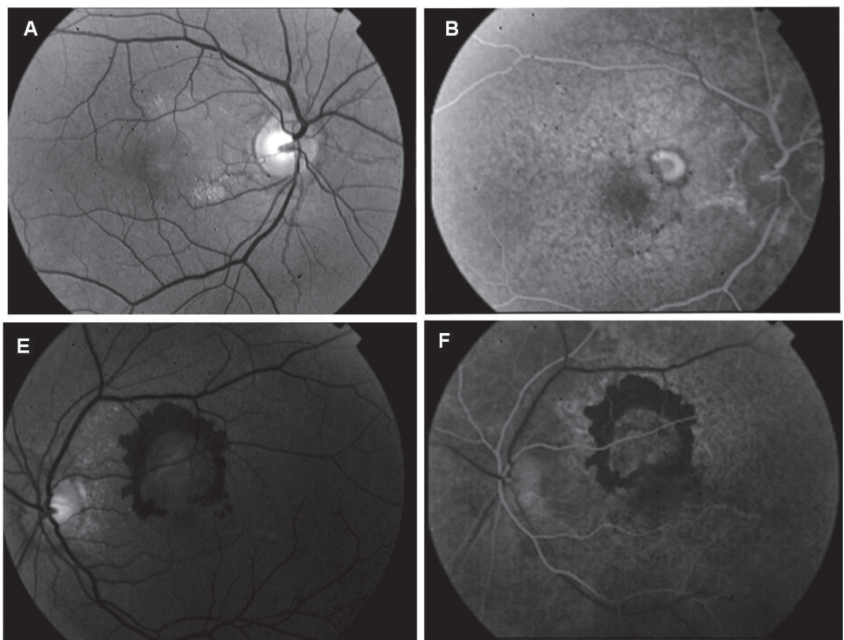
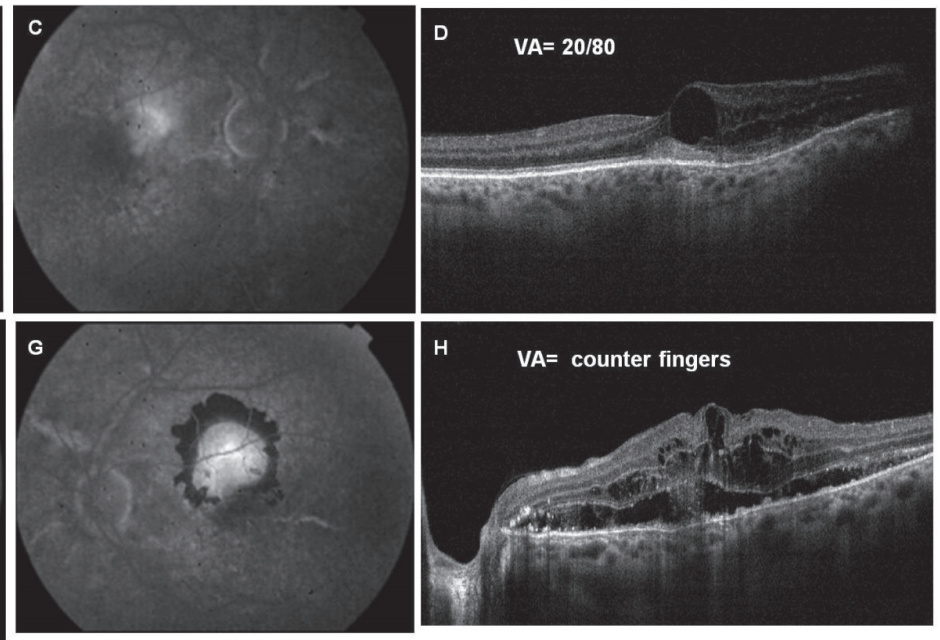

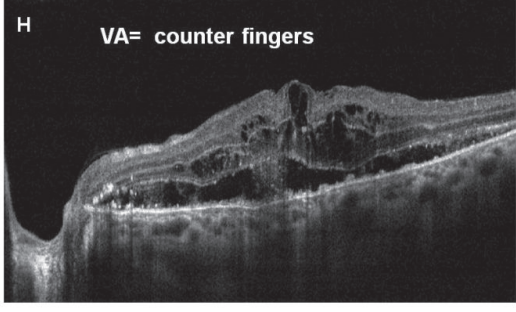

Figure 1: Forty eight year-old male, who has angiod streaks and bilateral subretinal neovascular membrane at baseline, red-free (A, E) of the both eyes, and fluorescein angiography (B-C) show an active juxtafoveal classic choroidal neovascularization in the right eye, and (F-G) a subfoveal predominantly classic choroidal neovascularization in the left eye, optical coherence tomography (D-H) shows the neovascular complex in both eyes 

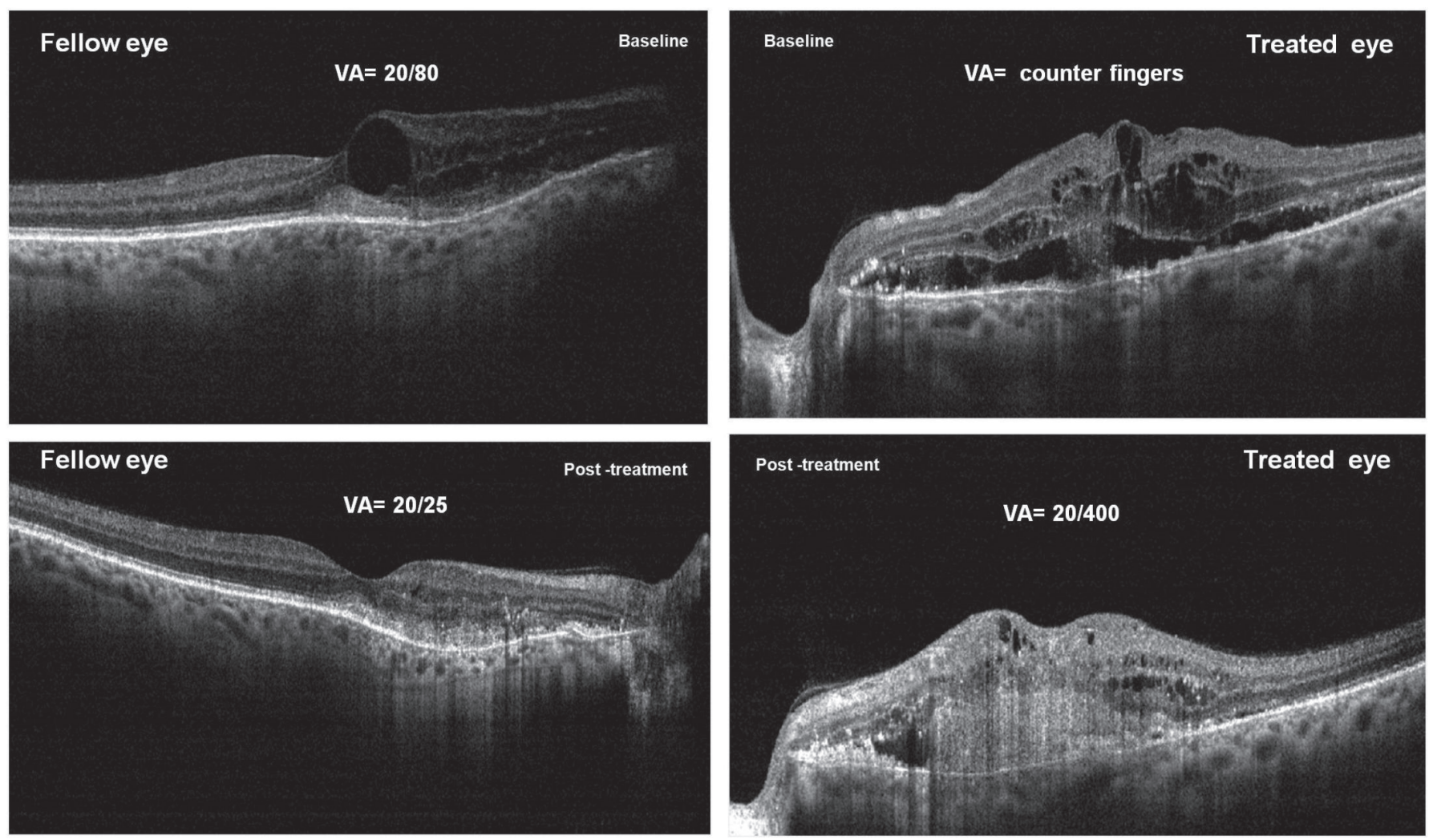

Figure 2:15-days after an unilateral intravitreal injections of ranibizumab (Lucentis) in the left eye; optical coherence tomography demonstrates regression of the neovascular complex in the right eye (fellow eye) and partial fluid absorption of the left eye (treated eye); there was improvement of vision in both eyes

following intravitreal bevacizumab in a 54-years old man treated with intravitreal bevacizumab for CNV secondary to high myopia. After the second injection, he showed a moderate vitritis in the fellow un-injected eye few hours after the treatment ${ }^{(4)}$. $\mathrm{Wu}$ and Sadda reported a case in which intravitreal bevacizumab and ranibizumab appeared to have effects in the fellow, uninjected eye: an 83-year-old man developed CNV in the left eye and had a previous macular oedema from branch retinal vein occlusion in the right eye. Intravitreal bevacizumab in the left eye improved macular oedema in the right eye temporarily. Subsequently, intravitreal ranibizumab in the left eye also resulted in significant reduction of macular oedema in the right eye. ${ }^{(5)}$

The present case had an active CNV in both treatment naive eyes secondary to angiod streaks. Effect of ranibizumab was observed in the treated eye, but the fellow eye had complete resolution of the CNV complex as shown on OCT (Figure 2). This result may be a response to systemic absorption of the medication.

Any alternative hypotheses are highly speculative and inconclusive, but the possible systemic absorption of the medication may cause tromboembolic complications inherent to anti-VEGF, even though safety of ranibizumab was highly tested in all multicenter clinical trials. In a recent press release from the Safety Assessment of Intravitreal Lucentis for AMD (SAILOR) trial of open-label intravitreal ranibizumab for neovascular age macular degeneration, a slight increased risk of strokes was reported in patients receiving the $0.5-\mathrm{mg}$ dose versus the $0.3-\mathrm{mg}$ dose $(1.2 \% \text { versus } 0.3 \%, P=0.02)^{(7)}$. Similarly, the ANCHOR and MARINA 1-year pooled results showed a slight increase in the rate of strokes and myocardial infarctions in patients receiving $0.5-\mathrm{mg}$ injections versus sham injections, although the risk was not statistically significant ${ }^{(8)}$.

The exact mechanism of how bevacizumab can affect the uninjected eye has not been elucidated. The molecule may escape into the systemic circulation. Ranibizumab, a much smaller molecule, may also possess this capacity, thus accounting for the purported slightly increased risk of thromboembolic events in clinical trials ${ }^{(7-8)}$. Given that ranibizumab has a molecular weight almost 3 times lower than bevacizumab ( 48 and $149 \mathrm{kDa}$, respectively), ranibizumab is expected to penetrate retinal layers more easily, as has been shown in an animal model ${ }^{(9)}$. Therefore, higher concentrations might be detected in the serum of treated patients, at least in the first days after the injection. Haughney et al claim that ranibizumab systemic exposure is negligible, since the serum ranibizumab concentrations, when measurable, were around $1 \mathrm{ng} / \mathrm{ml}^{(10)}$.

Therefore, the question of a possible effect on the fellow uninjected eye still remains. Evaluation of serum VEGF levels and VEGF levels in the fellow eye might provide sufficient evidence. In conclusion, ranibizumab may have therapeutic effects in the uninjected fellow eye, possibly because they may escape from the eye into the systemic circulation. However, further studies are warranted to determine more precisely its safety in the treatment of CNV associated with angiod streaks.

\section{REFERENCES}

1. Piro PA, Scheraga D, Fine SL. Angioid streaks: natural history and visual prognosis. In: Fine SL, Owens SL, eds. Management of Retinal Vascular and Macular Disorders. Baltimore: Williams \& Wilkins, 1983:136-9. 
2. Neri P, Salvolini S, Mariotti C, Mercanti L, Celani S, Giovannini A Long-term control of choroidal neovascularisation secondary to angioid streaks treated with intravitreal bevacizumab (Avastin). $\mathrm{Br} \mathbf{J}$ Ophthalmol. 2009;93:155-8.

3. Al-Dhibi H, Khan AO. Bilateral response following unilateral intravitreal bevacizumab injection in a child with uveitic cystoid macular edema. J AAPOS 2009;13:400-402.

4. Neri P, Mariotti C, Mercanti L, Salvolini S, Giovannini A. Vitritis in the contralateral uninjected eye following intravitreal bevacizumab (Avastin). Int Ophthalmol 2008;28:425-27.

5. Wu Z, Sadda SR. Effects on the contralateral eye after intravitreal bevacizumab and ranibizumab injections: a case report. Ann Acad Med Singapore 2008;37:591-3.

6. Lazaros K, Leonidas Z. Intravitreal ranibizumab as primary treatment for neovascular membrane associated with angioid streaks. Acta Ophthalmol.2010;100-1. Letter to Healthcare Provider:Available at: http://www.gene.com/gene/products/information/pdf/healthcare-provider-letter.pdf. Accessed 27 September 2007.
8. Rosenfeld PJ, Rich RM, Lalwani GA. Ranibizumab: phase III clinical trial results. Ophthalmol Clin North Am 2006;19:361-72.

9. Gaudreault J, Fei D, Beyer JC, Ryan A, Rangell L, Shiu V et al: Pharmacokinetics and retinal distribution of ranibizumab, a humanized antibody fragment directed against VEGF-a, following intravitreal administration in rabbits. Retina 2007; 27:1260-1266.

10. Haughney PC, Lowe J, Kearns A: Clinical pharmacokinetics of ranibizumab (Lucentis) in subjects with AMD (ARVO abstract). Invest Ophthalmol Vis Sci 2005;46.

\section{Author corresponding:}

Otacilio O. Maia Jr.

Retina and Vitreous Service, Department of Ophthalmology

Hospital São Rafael - Monte Tabor Foundation

Av. São Rafael, 2.142 - São Marcos

CEP 41253-190 - Salvador (BA), Brazil

E-mail: otacilio.maia@hsr.com.br 